\title{
UPAYA KEPALA SEKOLAH DALAM MENINGKATKAN MUTU PENDIDIKAN DI MTS NURUL IKHLAS KOTA BEKASI
}

\author{
Ilyas Prasetyo \\ Universitas Singaperbangsa Karawang \\ Email: ilyas.prst98@gmail.com
}

\begin{abstract}
Abstrak
Penelitian ini bertujuan untuk meneliti upaya kepala sekolah dalam meningkatkan mutu pendidikan di sekolah MTs Nurul Ikhlas Kota Bekasi. Subjek dari penelitian ini adalah MTs Nurul Ikhlas Kota Bekasi. Instrumen penelitian yang digunakan adalah wawancara, dokumentasi dan observasi, melalui pendekatan kualitatf yang dijelaskan secara deskriptif. Berdasarkan hasil penelitian, peneliti menyimpulkan bahwa kepala sekolah di MTs Nurul Ikhlas Kota Bekasi berupaya sungguh-sungguh dalam meningkatkan mutu di sekolahnya. Upaya untuk meningkatkan mutu dalam guru di MTs Nurul Ikhlas Kota Bekasi diantaranya dengan memberikan izin dan motivasi terhadap untuk mengikuti diklat dan seminar.
\end{abstract}

\section{Kata kunci: Upaya Kepala Sekolah, Peningkatan Mutu Pendidikan, Kualitas.}

\section{A. PENDAHULUAN}

Perkembangan ilmu pengetahuan dan teknologi telah membawa perubahan di hampir semua aspek kehidupan manusia di mana berbagai permasalahan hanya dapat dipecahkan kecuali dengan upaya penguasaan dan peningkatan ilmu pengetahuan dan teknologi. Selain bermanfaat bagi kehidupan manusia, di satu sisi perubahan tersebut juga telah membawa manusia ke dalam era persaingan global yang semakin ketat. Agar mampu berperan dalam persaingan global, maka sebagai bangsa kita perlu terus mengembangkan dan meningkatkan kualitas sumber daya manusianya. Oleh karena itu, kalau tidak ingin bangsa ini kalah bersaing dalam menjalani era 
globalisasi tersebut, peningkatan sumber daya manusia harus dilakukan secara terencana, terarah, intensif, efektif, dan efisien dalam proses pembangunan (Satrijo \& Sudarmiani, 2018;86).

Walaupun demikian, agar mutu tetap terjaga dan agar proses peningkatan mutu tetap terkontrol, maka harus ada standar yang diatur dan disepakati secara nasional untuk dijadikan indikator evaluasi keberhasilan peningkatan mutu tersebut tersebut (adanya benchmarking). Pemikiran ini telah mendorong munculnya pendekatan baru, yakni pengelolaan peningkatan mutu pendidikan di masa mendatang harus berbasis sekolah sebagai institusi paling depan dalam kegiatan pendidikan. Pendekatan ini, kemudian dikenal dengan manajemen peningkatan mutu pendidikan berbasis sekolah (School Based Quality Management) atau dalam nuansa yang lebih bersifat pembangunan (development) disebut School Based Quality Improvement (Satrijo \& Sudarmiani, 2018;88).

Programme for International Study Assessment (PISA) pada tahun 2012 menempatkan Indonesia sebagai salah satu negara dengan peringkat terendah dalam pencapaian mutu pendidikan. Dalam studi yang dilakukan oleh PISA, mutu pendidikan Indonesia yang rendah dikonfirmasi dengan anggaran dan biaya pendidikan yang langsung dibayar masyarakat naik signifikan dari tahun ke tahun. PISA merupakan studi internasional yang diselenggarakan Organization for Economic Cooperation and Development (OECD).

UNESCO pada tahun 2012 menyajikan laporan bahwa Indonesia berada di peringkat ke-64 dari 120 berdasarkan penilaian Indeks Pembangunan Pendidikan (Education Development Index / EDI). Total nilai EDI itu diperoleh dari rangkuman perolehan empat kategori penilaian, yaitu angka partisipasi pendidikan dasar, angka melek huruf pada usia 15 tahun ke atas, angka partisipasi menurut kesetaraan gender, angka bertahan siswa hingga kelas V Sekolah Dasar. Sementara itu, The United nations Devlopment Index (HDI) Indonesia mengalami penurunan dari peringkat 108 negara. Sementara pada tahun 2013 dilaporkan naik tiga peringkat menjadi urutan ke 121 dari 185 negara. Data ini meliputi aspek tenaga kerja, kesehatan, dan pendidikan (Donni dan Rismi, 2014;2).

Salah satu indikator keberhasilan kepemimpinan seorang kepala sekolah diukur dari mutu pendidikan yang ada di sekolah yang dipimpinnya. Dalam konteks pendidikan, pengertian mutu mencakup input, proses, dan output pendidikan (Depdiknas, 2001:5). Penyebab rendahnya mutu pendidikan di Indonesia tentu tidak lepas dari peran dan kepemimpinan seorang kepala sekolah sebagai top leadernya. Melihat pentingnya fungsi kepemimpinan kepala sekolah, maka usaha 
untuk meningkatkan kinerja yang lebih tinggi bukanlah pekerjaan mudah bagi kepala sekolah karena kegiatan berlangsung dalam sebuah proses panjang yang direncanakan dan diprogram secara baik pula. Namun pada kenyataannya tidak sedikit kepala sekolah yang hanya berperan sebagai pimpinan formalitas dalam sebuah sistem alias hanya sekedar sebagai pemegang jabatan struktural sambil menunggu masa purna tugas.

Artinya: Bagi manusia ada malaikat-malaikat yang selalu mengikutinya bergiliran, di muka dan di belakangnya, mereka menjaganya atas perintah Allah. Sesungguhnya Allah tidak merubah keadaan sesuatu kaum sehingga mereka merubah keadaan yang ada pada diri mereka sendiri. Dan apabila Allah menghendaki keburukan terhadap sesuatu kaum, maka tak ada yang dapat menolaknya; dan sekali-kali tak ada pelindung bagi mereka selain Dia. (Ar-Ra'd 13:11)

Ketercapaian tujuan pendidikan sangat bergantung pada kecakapan dan kebijaksanaan kepemimpinan kepala sekolah yang merupakan salah satu pemimpin pendidikan. Karena kepala sekolah merupakan seorang yang profesional dalam organisasi sekolah yang bertugas mengatur semua sumber organisasi dan bekerjasama dengan guru-guru dalam mendidik siswa untuk mencapai tujuan pendidikan.

\section{B. PEMBAHASAN}

\section{Definisi Kepala Sekolah}

\section{a. Pengertian Kepala Sekolah}

Keberhasilan suatu lembaga pendidikan salah satunya dipengaruhi oleh pola atau struktur kepemimpinan kepala sekolah. Karena kepala sekolah sebagai pemimpin di lembaganya, maka seorang kepala sekolah diharapkan mampu membawa lembaga yang di pimpinnya kearah tercapainya tujuan yang telah ditetapkan, kepala sekolah harus mampu melakukan suatu perubahan serta mampu melihat masa depan dalam kehidupan globalisasi yang lebih baik. Kepala sekolah harus bertanggungjawab atas kelancaran dan keberhasilan semua urusan pengaturan dan pengelolaan sekolah secara formal kepada atasannya atau informal kepada masyarakat yang telah menitipkan anak didiknya.

Kepala sekolah adalah tenaga fungsional guru yang diberi tugas untuk memimpin suatu sekolah dimana diselenggarakan proses belajar mengajar atau tempat dimana terjadi interaksi 
antara guru yang memberi pelajaran dan murid yang menerima pelajaran (Wahjusumidjo,2005:83).

\section{b. Manajemen Kepala Sekolah}

Secara sederhana manajemen bisa dikatakan sebagai suatu seni untuk mengelola organisasi mencapai keberhasilan mewujudkan cita ideal bersama. Karenanya, manajemen menurut Michael Armstrong merupakan suatu proses menentukan apa yang perlu dilakukan dan kemudian menyelesaikannya melalui penggunaan sumberdaya secara efektif (Michael Armstrong, 2009:3). Dari pengertian ini dapat dipahami bahwa manajemen muncul untuk mengatur arah dan tujuan organisasi yang hendak diwujudkan melalui pendayagunaan sumber daya yang ada secara arif dan efektif (Yuliharti \& Umiarso, 2019:13). Pelaksanaan manajemen sekolah, baik yang konvensional maupun yang menggunakan pendekatan berbasis sekolah, akan dapat berhasil dan berjalan dengan baik jika didukung oleh kepemimpinan kepala sekolah yang secara fungsional mampu berperan sesuai dengan tugas, wewenang, dan tanggung jawabnya. Dia dituntut mampu mensinergikan seluruh komponen dan potensi sekolah dan lingkungan sekitarnya agar tercipta kerja sama untuk memajukan sekolah.

Kepala sekolah harus mampu menjadi manajer yang efisien dan pimpinan yang efektif. Dia harus mencerminkan tampilan kekepalasekolahan sejati, yaitu memiliki kemampuan manajemen dan dapat menampilkan sikap dan sifat sebagai kepala sekolah. Istilah kekepalasekolahan bermakna segala seluk-beluk yang berkaitan dengan tugas kepala sekolah. Perilaku kekepalasekolahan tercemin dari kristalisasi interaksi antara fungsi organik manajemen (perencanaan, pengorganisasian, pelaksanaan, pengawasan dan pengendalian, serta evaluasi dan pelaporan) dengan fungsi substantif, yaitu akademik, ketenagaan, keuangan, fasilitas, kehumasan, pelayanan khusus, dan sebagainya. Fungsi organik manajemen merupakan roda gigi dalam menjalankan fungsi substantif. Interaksi sinergis keduanya melahirkan sosok perilaku kekepalasekolahan ideal, yaitu yang mampu membawa organisasi sekolah untuk mencapai tujuan secara efektif dan efisien.

Peningkatan mutu pendidikan persekolahan sangat ditentukan oleh kemampuan kepala sekolah dalam memberdayakan staf pengajar dan anggota komunitasnya secara keseluruhan. Peran utama kepala sekolah antara lain adalah mengembangkan agar sekolah menjadi lembaga pendidikan yang baik dan mampu mencapai tujuan pendidikan. Kepala sekolah 
bertanggungjawab menjaga dan memotivasi guru, peserta didik, dan staf administrasi sekolah agar mau dan mampu melaksanakan ketentuan dan peraturan yang berlaku di sekolah. Di sinilah esensi bahwa kepala sekolah harus mumpuni menjalankan peran kekepalasekolahan (school principalship), berikut kemampuannya di bidang manajemen sekolah (Sudarwan \& Suparno, 2009:12-13).

Menurut Fayol yang dikutip Robbins, ada lima fungsi manajemen, yaitu merencanakan, mengorganisasikan, memerintah, mengkoordinasikan, dan mengendalikan. Stoner membagi fungsi manajemen ada empat yaitu: (1) merencanakan (planning); (2) mengorganisasikan (organizing); (3) memimpin (leading); dan (4) mengendalikan (controlling), Stoner tidak memasukkan fungsi memerintah dan mengkoordinasikan, karena memerintah sudah termasuk dalam fungsi leading dan mengoordinasi sudah termasuk dalam fungsi organizing.

a. Merencanakan

Dalam kerangka manajemen sseskolah, perencanaan bermakna bahwa kepala sekolah bersama timnya harus berpikir untuk menentukan sasaran-sasaran dikaitkan dengan kegiatan mereka sebelumnya. Kegiatan itu lebih didasari atas metode, pemikiran logis, dan analitis ketimbang pada praduga (intuitif). Meskipun dalam kenyataan, perencanaan yang efektif memerlukan kemampuan intuitif dan daya analisis. Porsi pemikiran strategis dari proses ini bersandar pada intuisi dan porsi analitis sangat sedikit. Perencanaan jangka panjang memerlukan keseimbangan di antara keduanya, sementara porsi perencanaan taktis sangat bersandar pada daya analitis. Intuisi terutama berfungsi sebagai pengecek dan penyeimbang. Untuk menjamin pencapaian hasil akhir dari perencanaan, kepala sekolah harus berpijak pada data yang cermat dan akurat. Rencana memberikan arah sasaran bagi organisasi dan mencerminkan prosedur terbaik untuk mencapai sasaran tersebut. Selain itu, rencana memungkinkan;

- Sekolah dapat memperoleh serta mengikat sumber daya yang diperlukan untuk mencapai tujuannya;

- Anggota organisasi dapaat melanjutkan kegiatan-kegiatan secara konsisten dengan tujuan dan prosedur yang telah dipilih; dan

- Kemajuan ke arah tujuan dapat dipantau dan diukur, sehingga tindakan perbaikan dapat diambil apabila kemajuan itu tidak memuaskan.

b. Mengorganisasikan 
Mengorganisasikan adalah suatu proses pengaturan dan pengalokasian kerja, wewenang, dan sumber daya di kalangan anggota sehingga mereka dapat mencapai tujuan organisasi secara efisien. Kepala sekolah harus memiliki kemampuan menentukan jenis program yang dibutuhkan dan mengorganisasikan semua potensi yang dimiliki untuk mencapai tuuan yang telah ditentukan. Setelah rencana program disusun dan pembagian tugas telah dilakukan, kegiatan selanjutnya adalah mengatur langkah ke arah sasaran organisasi yang telah ditetapkan. Fungsi ini dikenal dengan pelbagai sebutan, seperti memimpin, mengarahkan, memotivasi, dan menggerakan. Fungsi ini dimaksudkan agar anggota organisasi sekolah atau staf pengajar dapat bekerja dengan cara-cara yang akan membantu tercapainya sasaran yang telah ditetapkan.

Penjelasan di atas menggariskan bahwa kepala sekolah harus dapat membimbing, mengatur, mempengaruhi, menggerakan, mengkoordinasikan pelaksanaan tugas-tugas kependidikan di lembaga persekolahan agar berjalan teratur, penuh kerja sama. Juga, lahirnya kegairahan guru dan siswa dalam melaksanakan proses mengajar dan belajar. Perencanaan dan pengorganisasian, karenanya, berhubungan dengan aspek-aspek yang lebih abstrak dari proses manajemen. Sebaliknya dalam kegiatan pemimpin sangat konkret, karena hal itu langsung berhubungan dengan orang.

c. Mengendalikan

Melalui fungsi pengendalian, pemimpin dapat menjalankan organisasi agar tetap berproses pada arah yang benar dan tidak membiarkan deviasi atau penyimpangan yang terlalu jauh dari arah tujuan yang telah ditetapkan. Pengendalian dan supervise dilakukan untuk mengukur dan mengoreksi prestasi kerja bawahan guna memastikan, bahwa tujuan organisasi di semua tingkat dan rencana yang didesain dapat dilaksanakan secara baik. Fungsi pengendalian dalam manajemen mencakup empat unsur utama, yaitu:

- Menetapkan tujuan,

- Mengorganisasikan,

- Memotivasi,

- Mengkomunikasikan, dan

- Mengukur perkembangan kemampuan staf pengajar.

Selaras konsepsinya dengan pendapat tersebut di atas, secara lebih luas Mintzberg mengelompokkan perilaku pimpinan menjadi tiga bidang peranan yaitu : (1) peranan antarpribadi 
yaitu sebagai pemuka simbolis, pemimpin dan perantara; (2) peranan informasional yang meliputi monitoring, penerus informasi, perwakilan; dan (3) peranan pengambilan keputusan yang meliputi sikap wiraswasta, penangkal kesulitan, pengalokasian sumber daya, dan negosiator.

d. Mengkomunikasikan

Kemampuan berkomunikasi merupakan salah satu kompetensi yang harus dimiliki dan dikuasai oleh kepala sekolah. Berbekal kemampuan melakukan komunikasi yang efektif dengan guru, orang tua, siswa, dan masyarakat, dia akan mudah melaksanakan tugas pokok dan fungsinya. Komunikasi adalah proses penyampaian pesan, pikiran, dan gagasan oleh komunikator melalui media dan teknik yang menimbulkan efek tertentu, sehingga dapat mengubah sikap dan kepercayaan komunikan. Komunikasi dalam kerangka definisi ini cenderung diberi makna mengandung unsur persuasive. Hakikatnya komunikasi persuasif adalah mengubah atau memperkuat sikap atau kepercayaan khalayak untuk bertindak dengan cara tertentu.

Komunikasi persuasif ini mencakup empat aspek, yaitu paparan secara selektif, partisipasi khalayak, prinsip inokulasi, dan besaran perubahan. Kemampuan menyajikan pesan atau informasi merupakan kunci sukses berkomunikasi. Penggunaan prinsip partisipasi khalayak atau komunikan dalam komunikasi persuasif, merangsang adanya partisipasi aktif dari para komunikan dalam proses transformasional. Agar terjadi partisipasi yang baik, harus ada komunikasi timbal balik antara komunikator dengan komunikan. Kondisi ini berarti menimbulkan unsur pengikutsertaan dari bawahan kepada lembaga.

Penggunaan prinsip inokulasi, merupakan kemampuan pemimpin dalam memompakan keyakinan berupa antibodi kepada khalayak. Pemberian antibodi ini untuk memperkuat khalayak atau komunikan terhadap apa yang akan disampaikan. Tingkat efektifitas komunikasi sangat dipengaruhi oleh kredibilitas komunikator, yaitu sejauh mana tingkat kepercayaan dan daya tarik personalnya dalam menempatkan diri dalam anggota kelompok.

e. Mengawasi dan Mengendalikan

Pengawasan dan pengendalian dimaksudkan untuk mencegah deviasi. Pengawasan yang baik bersifat preventif. Pengendalian yang baik harus mampu mendorong aneka deviasi kembali pada 
rel tugas yang benar. Kegiatan pengawasan dan pengendalian ini harus dilakukan secara kontinyu, objektif, transparan, dan akuntabel.

\section{f. Melaporkan}

Pelaporan merupakan salah satu kegiatan organisasi. Substansi yang dilaporkan harus menggambarkan kondisi yang sebenarnya. Dengan pellaporan ini akan diketahui hasil-hasil yang dicapai, kendala yang muncul, dan penyimpangan yang terjadi. Laporan dapat dibuat secara berkala, misalnya, bulanan, atau tahunan. Laporan juga mestinya menjadi acuan dasar dalam kerangka

Sampai abad ke-21, kekepalasekolahan (principalship) kurang mendapat perhatian dalam hamper semua agenda utama pembaharuan pendidikan seperti yang dicatat oleh the Wallace Foundation (2012: 3), "mereka memandang kepemimpinan penting untuk meningkatkan sekolah, tetapi mereka tidak tahu bagaimana cara meningkatkannya. "Saat ini, peningkatan kepemimpinan sekolah naik peringkat satu dalam daftar pembaharuan sekolah. Manfaat dan tujuan kekepalasekolahan adalah memberikan wawasan kepada kepala sekolah tentang hal-hal teori dan praktik yang berkenaan dengan kepala sekolah (Husaini Usman, 2019:176).

Kepala sekolah tersusun dari dua kata, yaitu kepala dan sekolah. Kepala dapat diartikan sebagai ketua atau pemimpin dalam suatu organisasi atau lembaga. Sekolah merupakan sebuah lembaga tempat bernaungnya peserta didik untuk memperoleh pendidikan formal. Secara sederhana, kepala sekolah dapat didefinisikan sebagai tenaga fungsional guru yang diberi tugas untuk memimpin sekolah tempat diselenggarakan proses belajar mengajar, atau tempat dimana terjadinya interaksi antara guru yang memberi pelajaran dan peserta didik yang menerima pelajaran. Maksud memimpin tersebut adalah leadership, yaitu kemampuan untuk menggerakan sumber daya, baik internal maupun eksternal, dalam rangka mencapai tujuan sekolah dengan lebih optimal.

Kata memimpin mengandung konotasi menggerakan, mengarahkan, memimbing, melindungi, membina, memberikan, dan lain-lain. Husaini Usman (2008) menyatakan bahwa kepaala sekolah merupakan manajer yang mengorganisir seluruh sumber daya sekolah dengan menggunakan prinsip "TEAMWORK', yaitu rasa kebersamaan (together), pandai merasakan (empathy), saling membantu (assist), saling penuh kedewasaan (maturity), saling mematuhi (willingness), saling teratur (organization), saling menghormati (respect), dan saling berbaik hati (kindness). 
Menurut Mulyasa, Keberhasilan pendidikan di sekolah sangat ditentukan oleh keberhasilan kepala sekolah dalam mengelola tenaga kependidikan yang tersedia di sekolah. Kepala sekolah merupakan salah satu komponen pendidikan yang berpengaruh dalam meningkatkan kinerja guru. Kepala sekolah bertanggung jawab atas penyelenggaraan kegiatan pendidikan administrasi sekolah, pembinaan tenaga kependidikan lainnya, dan pendayagunaan serta pemeliharaan sarana dan prasarana.

Hal tersebut menjadi lebih penting sejalan dengan semakin kompleksnya tuntutan tugas kepala sekolah, yang menghendaki dukungan kinerja yang semakin efektif dan efisien. Di samping itu, perkembangan ilmu pengetahuan dan teknologi, serta seni dan budaya yang diterapkan dalam pendidikan di sekolah juga cenderung bergerak semakin maju, sehingga menuntut penguasaan secara prrofesional. Oleh karena itu kepala sekolah harus mempunyai kepribadian atau sifat-sifat dan kemampuan serta keterampilan-keterampilan untuk memimpin sebuah lembaga pendidikan secara profesional (Donni \& Rismi, 2014:50).

\section{C . HASIL PENELITIAN DAN PEMBAHASAN}

\section{Upaya Kepala Sekolah dalam Meningkatkan Mutu Pendidikan di MTs Nurul Ikhlas Kota Bekasi}

Kepala sekolah tidak hanya mengelola sekolah dalam makna statis, melainkan menggerakan semua potensi yang berhubungan langsung atau tidak langsung bagi kepentingan proses pembelajaran. Semua komunitas sekolah memerlukan bimbingan dan pembinaan dari kepala sekolah dalam upaya mewujudkan proses belajar yang efektif (Sudarwan \& Suparno, 2009:13).

Madrasah merupakan sekolah yang mengajarkan ilmu keagamaan, juga mengajarkan ilmuilmu yang diajarkan di sekolah umum. Ilmu keagamaan yang diajarkan di madrasah pada umumnya sudah ditentukan oleh Departemen Agama berupa mata pelajaran, Al-quran, Hadits, Akidah, Akhlak, Fikih dan Bahasa Arab. Madrasah Tsanawiyah Nurul Ikhlas Kota Bekasi merupakan sekolah swasta di bawah naungan Yayasan Pendidikan Islam Al Ikhlas.

Paparan data penelitian ini mengungkapkan data yang diperoleh dari hasil penelitian dengan menggunakan tehnik observasi, wawancara dan dikumentasi mengenai upaya kepala sekolah dalam meningkatkan mutu pendidikan agama Islam. Dalam hal ini sebagaimana yang disampaikan oleh bapak Achmad Zakaria, S.Ag selaku kepala sekolah, sebagai berikut : 
"Dalam upaya untuk meningkatkan mutu pendidikan dimulai dari tenaga pendidiknya, dengan mengikutkan para guru dalam pelatihan, seminar-seminar pendidikan dan umum, contohnya seminar Peningkatan kualitas belajar siswa, mengadakan kerja sama dengan lembaga pendidikan lain baik itu swasta atau negeri, menggerakkan kerja secara profesional dengan cara pembagian tugas secara jelas dan transparan. Juga saya selaku kepala sekolah selalu mendukung dan memberikan kesempatan sebanyak-banyaknya kepada para guru di MTs Nurul Ikhlas Kota Bekasi ini”.

"Kepala sekolah memiliki kewenangan untuk penyelenggaraan pelaksanaan proses belajar dengan aturan yang telah disepakati para guru maupun orang tua murid. Hal itu dilakukan agar planning yang sudah dirunding dapat berjalan secara baik, tetapi sebagai kepala sekolah juga tidak boleh bertindak otoriter akan tetapi lebih secara terbuka dengan guru, staf-staf lainnya atau bawahan yang bekerja di MTs Nurul Ikhlas Kota Bekasi ini”.

"Tetapi jika dalam hal sarana dan prasarana itu kembali kepada kebutuhan yang telah di rencanakan dan butuhkan pada saat masa globalisasi ini. Karena setiap keputusan dan perencanaan yang diambil sudah ada mekanisme sendiri dengan pertimbangan masukkan yang dikonsultasikan kepada kami. Kemudian dirundingkan kepada pihak Yayasan dan menyerahkannya untuk diberikan ketentuan” (Kamis, 11 Februari 2020, pukul 09.00).

Hal tersebut dikuatkan oleh pernyataan dari bapak Rafli, BA selaku wakil kepala sekolah, sebagai berikut:

"Kita dari pihak sekolah bukan hanya mengurusi dari segi sarana untuk peningkatan sekolah saja, tetapi dari siswa juga harus diperhatikan dari segi sikap dan kelakuan perlu diperhatikan, karena dari situlah kita bisa mengevaluasi apa saja yang bakal kita lakukan kedepannya yang dapat merubah atau bahkan meningkatkan kinerja pembelajaran guru dan mutu di sekolah ini” (Jum'at, 12 Februari 2020, pukul 09.00).

Berkaitan dengan yang dipaparkan oleh wakil kepala sekolah, maka dapat dikutip hasil wawancara dengan reponden lain yang di ungkapkan oleh ibu Dra, Siti Muthmainah selaku guru BP, sebagai berikut:

"Pada saat sebelum jam pelajaran dimulai dalam hal tersebut kepala sekolah harus memberikan himbauan-himbauan kepada siswa tentang nasihat berupa penanaman akhlak yang baik yang membuat pembejalaran sekolah lebih kondusif dan guru bisa dapat mengajar lebih 
nyaman dan efektif dan tidak ada hambatan apapun, walaupun memang tidak semua anak bisa berprilaku dengan baik” (Jum’at, 12 Februari 2020, pukul 10.30).

Dari hasil wawancara di atas dapat disimpulkan bahwa pengaruh yang dapat meningkatkan mutu pendidikan bukan dari kepala sekolah dan guru saja, tetapi peserta didik juga berpengaruh dalam meningkatkan mutu pendidikan terhadap guru yang sebagaimana nasihat-nasihat, usulan dan masukkan dari kepala sekolah pada saat sebelum pembelajaran dimulai yang mendapatkan efek motivasi, inovasi dan kondusif belajar di Madrasah Tsanawiyah Nurul Ikhlas Kota Bekasi. Berdasarkan dari visi madrasah di Madrasah Tsanawiyah Nurul Ikhlas Kota Bekasi, mutu pendidikan yang diterapkan untuk mendukung tercapainya tujuan pendidikan selain kurikulum nasional atau kurikulum dari pemerintah pusat adalah kurikulum muatan lokal. Kurikulum di Madrasah Tsanawiyah Nurul Ikhlas Kota Bekasi lebih mendalami dari segi keagamaan. Tujuan muatan lokal adalah agar lulusan yang dihasilkan mempunyai kemampuan pendidikan yang seimbang dengan ilmu kEagamaan dan ilmu pengetahuan umum.

Tantangan zaman semakin maju dan berkembang, maka Madrasah Tsanawiyah Nurul Ikhlas Kota Bekasi untuk mencapai keseimbangan ilmu pengetahuan umum dan ilmu pengetahuan keagamaan maka di butuhkan pelajaran agama yang sama potensinya dengan pelajaran umum. Sehingga adanya tujuan di terapkanya kurikulum muatan lokal yaitu peningkatan iman dan taqwa, peningkatkan akhlak mulia, peningkatan kompetensi, peningkatan kecerdasan, berbudi pekerti luhur, mandiri, terampil, sehat jasmani, cinta lingkungan dan cinta tanah air.

\section{A. PEMBAHASAN}

Penerapan upaya kepala sekolah dalam meningkatkan mutu pendidikan merupakan inovasi dalam pembangunan maupun kemajuan sekolah dalam perkembangan ilmu yang membawa perubahan pada semua aspek. Dasar dari pendidikan pendidikan tertera dalam Undang-undang Republik Indonesia Nomor 20 Tahun 2003 pasal 1, yang berbunyi pendidikan adalah usaha sadar dan terencana untuk mewujudkan suasana belajar dan proses pembelajaran agar peserta didik secara aktif mengembangkan potensi dirinya untuk memiliki kekuatan spiritual keagamaan, pengendalian diri, kepribadian, kecerdasan, akhlak mulia, serta keterampilan yang diperlukan dirinya, masyarakat, bangsa dan Negara.

Penerapan upaya kepala sekolah dalam meningkatkan mutu pendidikan di MTs Nurul Ikhlas

Kota Bekasi memiliki beberapa tujuan yaitu Membina berkembangnya akhlaq siswa, Mengembangkan kreativitas siswa, Meningkatkan prestasi siswa sesuai dengan potensi yang 
dimiliki, Menyiapkan siswa untuk dapat masuk di SLTA yang diinginkan baik di dalam maupun di luar negeri, Menyiapkan siswa untuk dapat menyusun karya ilmiah dalam bahasa Indonesia maupun dalam bahasa Inggris. Namun di dalam MTs Nurul Ikhlas Kota Bekasi berfokus pada tujuan yang menonjol dalam bidang keagamaan. Dalam meningkatkan mutu pendidikan kepala sekolah memberi motivasi secara terus menerus kepada guru untuk selalu mencari pengetahuan seluas-luasnya di luar sekolah, contohnya mengikuti seminar-seminar dan selalu mengikuti perkembangan teknologi dan pengetahuan umum atau bisa mengikuti study banding. Siswasiswa juga harus mempersiapkan diri untuk menerima pelajaran dari guru dengan cara disiplin, menjaga sopan santun, menghormati guru dengan demikian sesuai peraturan yang berlaku di sekolah, maka terjalin interaksi yang baik antara siswa dan guru, sehingga terjadi proses belajar mengajar dengan baik dan bisa berjalan dengan semestinya sesuai yang diharapkan. Dalam lingkungan/masyarakat juga tidak kalah penting dalam proses belajar mengajar di sekolah, contohnya ikut menjaga keamanan dan ketertiban di lingkungan sekolah sehingga tercipta proses belajar mengajar dengan tenang dan akan menumbuhkan rasa persatuan di antara lingkungan sekolah dan masyarakat. Untuk menggambarkan tingkat kualitas yang dapat dicapai serta mengacu pada Mutu Pendidikan dan Ilmu Keagamaan, maka Madrasah memiliki sasaran rencana, pelaksanaan dan evaluasi sebagai berikut:

a. Rencana

Memaksimalkan kegiatan belajar melalui Tahfidz Qur'an dan optimalisasi program kegiatan belajar melalui pelayanan terhadap siswa.

b. Pelaksanaan

Pelaksanaan pembelajaran penulis dapat menganalisis, dalam pelaksanaan pembelajaran di awali dengan membaca doa bersama dan memberikan motivasi kepada siswa, metode yang dilakukan macam-macam diantaranya metode ceramah dan tanya jawab.

c. Evaluasi

Pelaksanaan evaluasi dengan tes lisan dan tulis. Tes lisan dilaksanakan pada saat pembelajaran dan tes tulis dilaksanakan sesuai dengan jadwal akhir semester atau ujian tengah semester.

Dalam pengembangan konsep kepala sekolah dalam mutu pendidikan di MTs Nurul Ikhlas Kota Bekasi untuk meningkatkan mutu pendidikan kita lakukan dengan cara kerjasama antara kepala sekolah, guru, murid, orang tua dan staf lainya. Untuk biaya operasional sekolah bersumber dari 
SPP dan bantuan operasional sekolah (BOS) berupa dana, sarana dan prasarana prasarana pendidikan yang layak dan dibutuhkan siswa.

Dalam mutu pendidikan di MTs Nurul Ikhlas Kota Bekasi kepala sekolah, guru-guru dan para staf sudah bekerja secara maksimal dalam mengembangkan dan meningkatkan mutu sekolah, karena adanya komunikasi pada saat ada permasalahan di MTs Nurul Ikhlas Kota Bekasi.

\section{PENUTUP}

Dari keterangan dan uraian yang telah dikemukakan dalam bab-bab terdahulu, dapat peneliti jelaskan bahwa penelitian ini merupakan suatu bentuk analisi dari data-data yang berhasil peneliti kumpulkan dalam penelitian di Madrasah Tsanawiyah Nurul Ikhlas Kota Bekasi. Peneliti dapat menarik kesimpulan dari penelitian skripsi sebagai berikut:

1. Kepala sekolah di MTs Nurul Ikhlas Kota Bekasi berupaya sungguh-sungguh dalam meningkatkan mutu di sekolahnya. Upaya untuk meningkatkan mutu dalam guru di MTs Nurul Ikhlas Kota Bekasi diantaranya dengan memberikan izin dan motivasi terhadap untuk mengikuti diklat dan seminar.

2. Kepala sekolah MTs Nurul Ikhlas Kota Bekasi juga berupaya dengan sungguh-sungguh dalam memberikan motivasi, nasihat serta masukkan-masukkan kepada peserta didik dalam merubah sikap untuk pengaruh keefektifan pembelajaran yang menyangkut mutu pendidikan sekolah.

3. Dalam meningkatkan mutu pendidikan di MTs Nurul Ikhlas Kota Bekasi terdapat kerja sama kepada masyarakat yang dapat mengembangkan wujudnya visi dan misi di sekolah yang berkualitas baik.

4. Masyarakat juga berpengaruh dalam mutu pendidikan di MTs Nurul Ikhlas Kota Bekasi dalam hal administrasi, komunikasi dan kerja sama lainnya. 


\section{Daftar Rujukan}

Daryanto, Administrasi Pendidikan, (Jakarta: Rineka Cipta, 2001).

Donni Juni Priansa \& Rismi Somad, Manajemen Supervisi \& Kepemimpinan Kepala Sekolah, (Bandung: ALFABETA, 2014).

E. Mulyasa., 2005, Menjadi Kepala Sekolah Profesional Dalam Konteks Menyukseskan MBS

Dan KBK, cet. V, (Bandung: Rosda Karya, 2005).

Husaini Usman, Administrasi,, Manajemen, dan Kepemimpinan Pendidikan, (Jakarta: PT bumi Aksara, 2019).

Michael Armstrong, Armstrong's Handbook of Management and leadership: A Guide to Managing for Result, (London: Kogan Page Limited, 2009).

Oemar Hamalik, Proses Belajar Mengajar, (Jakarta:Bumi Aksara, 2003).

Satrijo Budiwibowo \& Sudarmiani, Manajemen Pendidikan, (Yogyakarta: ANDI, 2018).

Sudarwan Danim \& Suparno, Manajemen dan Kepemimpinan Transformasional Kekepalasekolahan, (Jakarta: PT RINEKA CIPTA, 2009).

Wahjusumidjo, Kepemimpinan Kepala Sekolah Tinjauan Teoritik dan Permasalahannya. (Jakarta: PT. Rajagrafindo Persada, 2005).

Yuliharti \& Umiarso, Konstruksi Teoritis dalam Manajemen Pendidikan Islam, (Jakarta: AMZAH, 2019). 